\title{
Solid household waste characterization and fresh leachate treatment: Case of Kasba Tadla city, Morocco
}

\author{
Fatima Benyoucef ${ }^{1}$, Abdelhadi Makan ${ }^{2,3^{\dagger}}$, Abderrahman El Ghmari ${ }^{1}$, Aziz Ouatmane ${ }^{4}$ \\ ${ }^{1}$ Ceology Department, University of Sultan Moulay Slimane, Beni Mellal 23000, Morocco \\ ${ }^{2}$ Chemistry Department, University of Chouaib Doukkali, El Jadida 24000, Morocco \\ ${ }^{3}$ ENQUAS Consulting, Environment Quality and Safety Consulting Office, Khouribga 25000, Morocco \\ ${ }^{4}$ Biology Department, University of Sultan Moulay Slimane, Beni Mellal 23000, Morocco
}

\section{ABSTRACT}

This study aims to characterize solid household waste and to present physicochemical characteristics of fresh leachate before landfilling in Kasba Tadla city, Morocco. Obtained results show that household waste produced in 2013 were about 11,787 tons, or 0.27 tons/capita/year. These wastes were composed essentially of organic materials $(74 \%)$, paper $(8 \%)$, plastics $(9 \%)$, metals $(1 \%)$, and glass $(0.5 \%)$. However, monthly produced leachate ranges from a maximum of $130.92 \mathrm{~m}^{3}$ during summer and a minimum of $21.88 \mathrm{~m}^{3}$ in winter. Moreover, leachate treatment using Upflow Anaerobic Sludge Blanket technique was accompanied by a decrease in electrical conductivity, certainly related to leachate-sediment chemical exchanges. Otherwise, the same acidity reduction phenomenon occurs when $\mathrm{pH}$ value increased from 4.49 to 6.17 after 24 hours, confirming the system response since the early stages of treatment. In addition, temporal evolution of the treatment efficiency in terms of COD highlighted a very important reduction which reached $94 \%$ after 5 days with an average temperature of $25^{\circ} \mathrm{C}$.

Keywords: Anaerobic treatment, Characterization, Household waste, Kasba Tadla city, Leachate, Up flow anaerobic sludge blanket

\section{Introduction}

Household waste is one of the largest produced wastes in Morocco. According to statistics of 2011, household waste is estimated to be 6.5 million tons per year [1]. This kind of waste generates large volume of leachate with high organic load and containing significant amounts of complex chemical compounds, which are difficult to degrade [2]. According to Kaschl et al. [3], much of this waste are simply discharged in wild landfills without any pretreatment, which constitute a real and permanent threat to the environment and public health.

Leachate sets as water that has percolated through waste and has charged with pollutants. These polluted effluents should be treated because of the growing demands of standards on liquid emissions [4]. New processing techniques have emerged in this area. The treatment using an Up-flow Anaerobic Sludge Blanket (UASB) is a technique that has been used for anaerobic treatment in many countries such as Brazil, Mexico, Colombia, Cuba, and Uruguay [5] at an ambient temperature of about $20^{\circ} \mathrm{C}$ and above. But according to Zeeman and Lettinga [6], this system can work even under conditions where temperature is between 5 and $20^{\circ} \mathrm{C}$, which will ensure effectiveness of the system throughout the year. In recent years, this technique has been used by many authors $[7,8]$. It was developed in the 1970s for the treatment of wastewater from food industry in Netherlands [9]. Then, this system has been become more efficient during the eighties and more efficient for other uses such as treatment of domestic wastewater. Later, in 1990, the first "Latin American Workshop on Anaerobic Digestion Seminar" was held in Mexico City, where the configuration of UASB was well accepted for treatment of wastewater in Europe. At present, with over a decade of experience in the field of treatment by UASB, some parameters seem to have reached acceptable values to scientific community, while other criteria are still unclear [10].

In this context, several authors $[5,6,9,11]$ reported that the system performance is directly related to influent organic load and hydraulic retention time (HRT) in the reactor. After treatment with UASB, the reduction in COD generally reaches values that range from $80 \%$ to $95 \%$ [5].

Population structure of Kasba Tadla city is characterized by an average size, with an annual growth rate of $1.1 \%$. However, the population of the city would be 45,131 inhabitants in 2015
This is an Open Access article distributed under the terms of the Creative Commons Attribution Non-Commercial License (http://creativecommons. org/ licenses/by-nc/3.0/) which permits unrestricted non-commercial use, distribution, and reproduction in any medium, provided the original work is properly cited.
Received July 27, 2015 Accepted September 21, 2015

${ }^{\dagger}$ Corresponding author

Email: abdelhadi.makan@gmail.com

Tel: +212-674-77-36-36 Fax: +212-0523-34-21-87

Copyright (C) 2015 Korean Society of Environmental Engineers 
[12]. The annual production of household waste is quite important given that it was about 11,787 tons/year on 2013. These quantities of waste generate a leachate volume of about $945.61 \mathrm{~m}^{3} /$ year.

Therefore, the present work consist firstly to evaluate composition and characteristics of fresh leachate generated from household waste in Kasba Tadla city before landfilling, to determine the monthly volume of this discharges, and finally to achieve treatment trials by UASB technique in an anaerobic reactor. The aim of this work is also to test the effectiveness of treatment using UASB technique through determining the appropriate HRT for a reduction of more than $90 \%$ COD to reduce pollution load and bring these effluents towards neutrality. The choice of this technique is due to several factors: it is an effective technique, less expensive, easy to use and does not require much installation.

\section{Materials and Methods}

\subsection{Composition of Household Waste}

The composition of household waste in Kasba Tadla city was determined by manual sorting. Firstly, 12 household waste bins of $360 \mathrm{~L}$ were collected from three zones (villa zone, economic zone and activity zone). Then, the packer truck was weighed using a weighbridge. The next step was the unloading of collected waste on a sorting platform. After this, discharged waste was sorted according to different fractions. Then, sorted materials were placed into plastic bags. Finally, bags of sorted materials were weighed. This test was replicated every month for the period between 2011 and 2013.

\subsection{Monitoring Produced Leachate}

Leachate monitoring was conducted by recovering and weighing leachate collected in the leachate tank within the packer truck. Recovered volume determination was deduced from the difference in the packer truck weight at the beginning and the end of collection shift. The test was performed once a week since January 2013

\subsection{Moisture Determination}

Waste moisture was determined by natural drying in open air. Samples were collected and packed in a grid. They were weighed, exposed to the sun, regularly using a "crane scale" until weight stabilization. Test sample for this determination corresponds to a weight of $80 \mathrm{~kg}$ [13]. The process was replicated 20 times.

\subsection{Physicochemical Characteristics of Leachate}

The Chemical Oxygen Demand (COD) was determined according to potassium dichromate method and Total Suspended Solids (TSS) was measured using the centrifugation method [14]. The Electrical Conductivity (EC) was measured in situ using an EC-214 conductivity meter (HANNA Instruments; Agadir, Morocco). The leachate $\mathrm{pH}$ and turbidity were measured before and during treatment (Accumet AB15 pH-meter; Fisher Scientific, Belgium). Physicochemical characteristics of raw leachate are given in Table 1.
Table 1. Physicochemical Characteristics of Raw Leachate

\begin{tabular}{lcc}
\hline \multicolumn{1}{c}{ Parameters } & Values & Unit \\
\hline Electrical Conductivity (EC) & 26,930 & $\mu \mathrm{s} / \mathrm{cm}$ \\
$\mathrm{pH}$ & 4.88 & - \\
$\mathrm{COD}$ & 23,500 & $\mathrm{mg} / \mathrm{L}$ \\
Fat & 370 & $\mathrm{~g} / \mathrm{L}$ \\
Turbidity & 2,890 & $\mathrm{NTU}$ \\
Total Suspended Solids (TSS) & 5,552 & $\mathrm{mg} / \mathrm{L}$ \\
{$\left[\mathrm{NH}_{4}^{+}{ }^{+}\right.$} & 1,990 & $\mathrm{mg} / \mathrm{L}$ \\
$\left.\mathrm{Cl}^{-}\right]$ & 2570 & $\mathrm{mg} / \mathrm{L}$ \\
Heavy Metals & 75 & $\mathrm{mg} / \mathrm{L}$ \\
Organic compounds & $55 \% \mathrm{VFA}$ & $\mathrm{mg} / \mathrm{L}$ \\
\hline
\end{tabular}

\subsection{Experimental Protocol for UASB Technique}

The experimental protocol used in this study consists of a buffer tank and a digester, UASB kind, of 200 liters capacity, $0.93 \mathrm{~m}$ height and $0.58 \mathrm{~m}$ diameter (Fig.1). The UASB digester is designed to handle an amount of leachate that represents approximately $1 / 10$ of the daily produced amount.

Anaerobic conditions optimization and sludge-leachate-biogas separation were facilitated by a metallic colon linked to the digester ceiling and immersed into leachate to a depth of $0.24 \mathrm{~m}$. Feeding the digester was performed continuously after the daily recovering of leachate from the packer truck tank during transportation to the landfill. To reduce the phase of stabilization and methanogenic flora adaptation, the digester was inoculated in the early stage of testing with $3 \mathrm{~kg}$ of natural sludge. This amount of sludge acts as a support media for biofilm formation. After the start-up, the reactor was filled with leachate for a period of five months in order to give birth to suitable biofilm for the treatment process. Subsequently, the reactor was emptied without altering the biofilm.

Treatment efficiency was monitored by one-liter samples taken from the buffer tank at the digester outlet for a period of 5 days. Samples were taken at the head of each 24 hours interval, corresponding to HRTs of 24, 48, 72, 96 and 120 hours. The reactor was operated 10 days with a permanent flow for each HRT. The

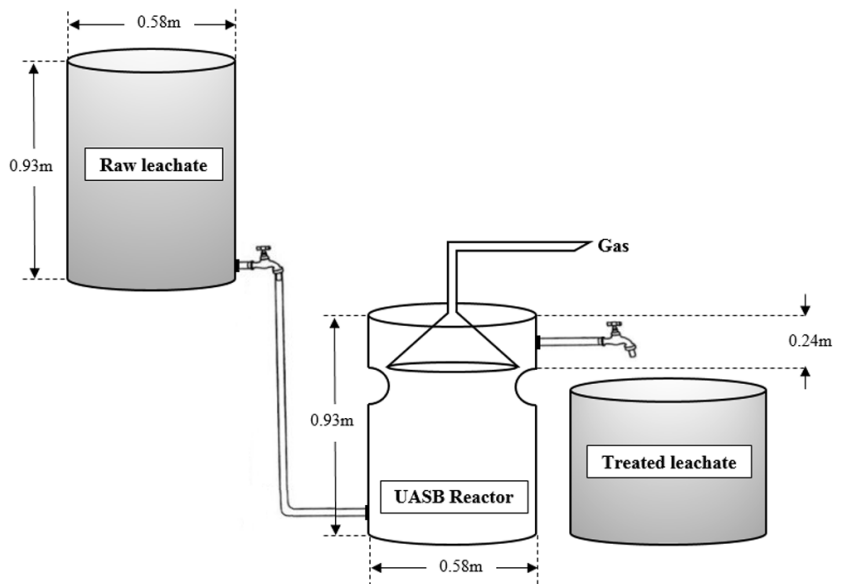

Fig. 1. Experimental protocol for the UASB reactor. 
samples were then placed into plastic bottles in an insulated box and transported directly to the laboratory for analysis [15]. The test was replicated three times during February and March 2013.

\section{Results and Discussion}

\subsection{Evolution of Household Waste Amount}

Table 2 shows the evolution of household waste amount produced between 2011 and 2013 in Kasba Tadla city. According to this table data, it is very clear that the waste amount has increased with demographic increasing of the population. However, the consumption trend has remained the same with recording the value of $0.74 \mathrm{~kg}$ as an average of produced waste per capita par day. This value is approximately identical to the amount produced at national level which is equals to $0.75 \mathrm{~kg}$ per capita per day [16].

\subsection{Composition of Household Waste}

Results relative to the analysis of household waste composition in Kasba Tadla city are reported in Table 3. From these results, organic matter (OM) is the dominant class which also includes unclassified wastes by a percentage of about $74 \%$ on average. This later varies according to consumption, nature and composition of dumped waste [17]. Moreover, paper and plastic classes are measured at $8 \%$ and $9 \%$ respectively, while aluminum, iron and glass amounts remain very negligible; less than $2 \%$. These results are similar to those found in other Moroccan cities and other countries [18-21].

It should be mentioned that the high content of $\mathrm{OM}$ in the produced waste may influence the volume of generated leachate during transportation. This volume will be more important in hot season due to the lixiviation process [22]. However, high temperature intervals may be suitable for water evaporation which, then, can be condensed in contact with any less hot materials.

\subsection{Moisture Content}

Moisture content of household waste in Kasba Tadla city varies between a maximum of $68 \%$ and a minimum of $56.25 \%$, with an average of about $61.71 \%$. The same results were also found in household waste of other Moroccan cities [2]. As high temperature intervals, high moisture content influences the amount of leachate produced during waste transportation to the landfill. However, achieving a very high volume of leachate is then predictable.

\subsection{Quantification and Characterization of Leachate}

\subsubsection{Leachate production monitoring}

Household waste leachates are effluents extremely loaded in organic and mineral pollutants and in toxic elements [23]. As the amount of leachate production varies according to consumption, nature and composition of waste, volume of leachate produced during collection was monitored for two years. Fig.2 shows mean values of the monthly produced leachate amount together with the standard deviations during 2013 and 2014. The results show that leachate volumes vary between a maximum volume of $130.92 \mathrm{~m}^{3}$ during August 2013 and a minimum volume of $21.88 \mathrm{~m}^{3}$ in December 2013, with a monthly average of about $78.80 \mathrm{~m}^{3}$. The annual evolution also showed that July and August are largest months in production terms. This is mainly due to the consumption type during the summer season, which is characterized by the abundance of high moisture fruit waste. Another reason may be the excessive heat during this season, which favors the release of leachate under greenhouse effect.

Table 2. Evolution of Household Waste Amount Produced in Kasba Tadla City (2011-2013)

\begin{tabular}{lccc}
\multicolumn{1}{c}{ Year } & $\mathbf{2 0 1 1}$ & $\mathbf{2 0 1 2}$ & $\mathbf{2 0 1 3}$ \\
\hline Estimated population (inhabitant) & 43,198 & 43,673 & 44,154 \\
Amount of household waste (ton/year) & 11,529 & 11,656 & 11,787 \\
Amount of household waste (kg/inhabitant/day) & 0.74 & 0.74 & 0.74 \\
\hline
\end{tabular}

Table 3. Composition of Household Waste in Kasba Tadla City (2011-2013)

\begin{tabular}{|c|c|c|c|c|c|c|}
\hline \multirow{2}{*}{ Description } & \multicolumn{2}{|c|}{ Average 2011} & \multicolumn{2}{|c|}{ Average 2012} & \multicolumn{2}{|c|}{ Average 2013} \\
\hline & Weight (kg) & $\%$ & Weight (kg) & $\%$ & Weight (kg) & $\%$ \\
\hline Colorless PET & $14 \pm 1.02$ & $1.65 \pm 0.11$ & $5 \pm 0.65$ & $0.65 \pm 0.11$ & $5.00 \pm 0.65$ & $0.56 \pm 0.09$ \\
\hline Colored PET & $25 \pm 0.83$ & $2.97 \pm 0.29$ & $33 \pm 1.95$ & $4.27 \pm 0.41$ & $3.00 \pm 0.34$ & $0.34 \pm 0.04$ \\
\hline PVC & $16 \pm 1.14$ & $1.9 \pm 0.24$ & $3 \pm 0.34$ & $0.39 \pm 0.06$ & $4.00 \pm 0.55$ & $0.45 \pm 0.07$ \\
\hline Plastic Film & $42 \pm 1.19$ & $4.98 \pm 0.49$ & $65 \pm 5.47$ & $8.44 \pm 1.11$ & $94 \pm 12.54$ & $10.61 \pm 1.57$ \\
\hline Cardboard & $45 \pm 0.79$ & $5.34 \pm 0.49$ & $68 \pm 7.47$ & $8.82 \pm 1.27$ & $97 \pm 11.63$ & $10.96 \pm 1.57$ \\
\hline Aluminum & $0.5 \pm 0.12$ & $0.06 \pm 0.01$ & $0.5 \pm 0.12$ & $0.06 \pm 0.02$ & $1.00 \pm 0.22$ & $0.11 \pm 0.02$ \\
\hline Iron & $9.00 \pm 0.8$ & $1.07 \pm 0.15$ & $9.00 \pm 0.80$ & $1.17 \pm 0.15$ & $4.00 \pm 0.55$ & $0.45 \pm 0.06$ \\
\hline Glass & $9.00 \pm 1.13$ & $1.07 \pm 0.19$ & $17 \pm 2.17$ & $2.21 \pm 0.38$ & $12 \pm 1.95$ & $1.35 \pm 0.19$ \\
\hline Fabric & $16 \pm 1.12$ & $1.9 \pm 0.22$ & $26.5 \pm 3.1$ & $3.44 \pm 0.52$ & $20 \pm 3.77$ & $2.27 \pm 0.50$ \\
\hline $\mathrm{OM}$ & $673 \pm 76.32$ & $79.06 \pm 1.98$ & $550 \pm 74.16$ & $70.54 \pm 3.48$ & $650 \pm 69.45$ & $72.9 \pm 3.29$ \\
\hline TOTAL & $849.5 \pm 76.64$ & 100 & $777 \pm 72.3$ & 100 & $890 \pm 62.5$ & 100 \\
\hline
\end{tabular}

PET: Polyethylene terephthalate, PVC: Poly-vinyl chloride. 


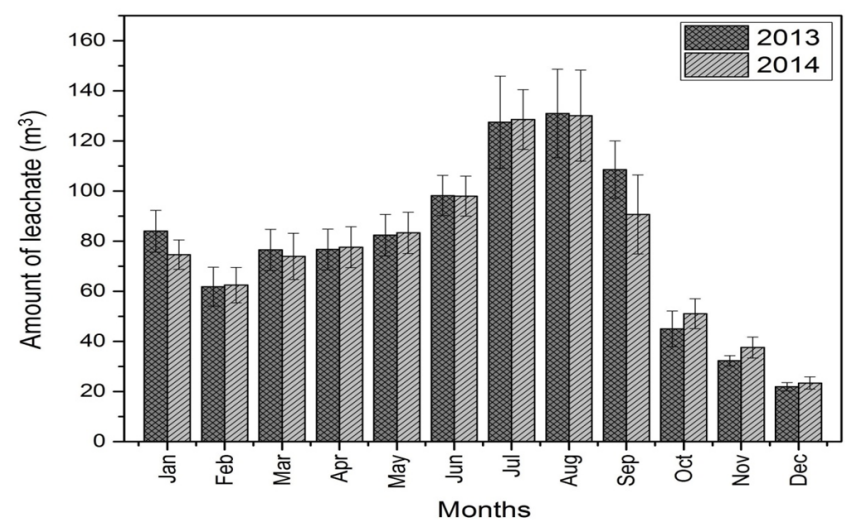

Fig. 2. Monthly change in the amount of leachate produced during 2013 and 2014.

\subsubsection{Characterization of leachate during UASB treatment}

Chemical and biochemical composition of leachate are not only very different but also variable in time and space. However, determination of overall composition of these discharges is most frequently done through physicochemical analyzes [24]. The physicochemical composition of leachate was determined both on raw leachate and treated leachate, according to Table 4 schedule, using UASB technique in order to evaluate efficiency of this treatment process.

The $\mathrm{pH}$ is an indicator allowing to be situated in various stages of effluent degradation. Fig. 3(a) shows the $\mathrm{pH}$ evolution as a function of the leachate HRT during the treatment. The $\mathrm{pH}$ values measured for different HRT depend on concentration change of volatile fatty acids. The $\mathrm{pH}$ monitoring indicates an acid character with a value of 4.49 recorded for raw leachate, frequently encountered within leachates in acidogenic phase [25, 26]. By increasing the HRT of the treatment, leachate $\mathrm{pH}$ has increased and stabilized, in subsequent phases, around approximately neutral value of 6.87 during methanogenesis. This $\mathrm{pH}$ increase may be explained by a denitrification reaction during which the consumption of protons, needed to reduce nitrates or nitrites to molecular nitrogen and/or nitrogen oxide gas, causes an increase in $\mathrm{pH}[27,28]$.

Turbidity and total suspended solids refer to particles present in the leachate. Turbidity is determined by the amount of light scattered off of these particles [29]. While this measurement can then be used to estimate the total dissolved solids concentration, it will not be exact. In addition, turbidity measurements may be affected by colored dissolved organic matter [30]. While this dissolved matter is not included in TSS measurements, it can cause artificially low turbidity readings as it absorbs light instead of scattering it [31]. The evolution of turbidity versus HRT is presented in Fig. 3(b). It decreases from 2890 to 491 NTU after an HRT of 5 days, recording about $83 \%$ of removal efficiency in terms of turbidity.

Total suspended solids, on the other hand, are a total quantity measurement of solid material per volume of water [29]. This means that TSS is a specific measurement of all suspended solids, organic and inorganic, by mass. TSS includes settleable solids, and is the direct measurement of the total solids present in a leachate body. As such, TSS can be used to calculate sedimentation rates, while turbidity cannot [29]. As the treatment proceed, the TSS was decreased in its turn from 5,552 to $1,308 \mathrm{mg} / \mathrm{L}$ after an HRT of 5 days (Fig. 3(c)), registering a TSS efficiency removal of about $77 \%$.

Measuring the EC provides a comprehensive information on the amount of charged species present within the leachate. It is an interesting parameter to follow in assessing mineral charges present in the effluent. The evolution of EC values is given in Fig. 3(d). The raw leachate has a high EC of about $26.72 \mathrm{mS} / \mathrm{cm}$ corresponding to the acidogenesis phase. Indeed, it is during this phase that the leaching of charged species is most important in view of low $\mathrm{pH}$ which promotes species solubilization. Moreover, greater values may also correspond to an accumulation of ions in leachate recirculation process [32]. During treatment, the EC evolution highlights regularly decreasing values, with respect to HRT in the UASB reactor, starting from the first day. Then, it was around $7.67 \mathrm{mS} / \mathrm{cm}$ and undergoes a decrease of $71 \%$ after an HRT of 5 days.

Organic matter released into the leachate is considered as good indicator of the effluent degradation state because it undergoes multiple transformations over the various degradation stages. The COD is one of the main parameters of which the measure is imposed by regulations. It determines the amount of oxidizable material present in the leachate and allows estimating the organic matter. The evolution of this parameter in the leachate was followed and is shown in Fig.4. The same trend as EC, TSS and turbidity was observed for the COD of leachate. The organic load of the raw leachate was approximately 25,700 mg/L. This high concentration may be due to the accumulation of species during the leaching process. Because of $\mathrm{pH}$ decrease due to Volatile Fatty Acids (VFA) concentration decrease, the organic load has decreased significantly and seems to stabilize around $1,542 \mathrm{mg} / \mathrm{L}$. This value corresponds to the values found in the literature for leachate in methanogenesis phase. It highlights a very important reduction which reaches $94 \%$ after an HRT of 5 days with an average temperature of $25^{\circ} \mathrm{C}$, which ranges from a maximum of $29^{\circ} \mathrm{C}$ and a minimum of $15^{\circ} \mathrm{C}$ during the study period. This reduction in COD was accompanied by an increase in biogas production during treatment. The amount of produced biogas has reached a value of $0.48 \mathrm{~L} / \mathrm{g}$ COD at an HRT of 5 days (Fig. 4). Approximately the same result was reported by Bohdziewicz and Kwarciak [33]. They found that at HRT equaled to 7 and 5 days, the biogas yield was approximately $0.50 \mathrm{dm}^{3}$ biogas $\times \mathrm{g}^{-1}$ COD. In addition, about $40 \%$ of the produced biogas was methane gas.

Given these results, it is noted that leachate treatment using UASB technique is accompanied by a decrease in EC, certainly related to leachate-sediment chemical exchanges. Otherwise, the same acidity reduction phenomenon occurs when $\mathrm{pH}$ value increases from 4.49 to 6.17 after 24 hours HRT, confirming system response since the early hours of startup processing UASB technique. These results are promising especially regarding COD reduction. The reduction of this later parameter was promptly recorded just after a few hours after UASB processing related to the organic matter biodegradation by anaerobic microorganisms, 

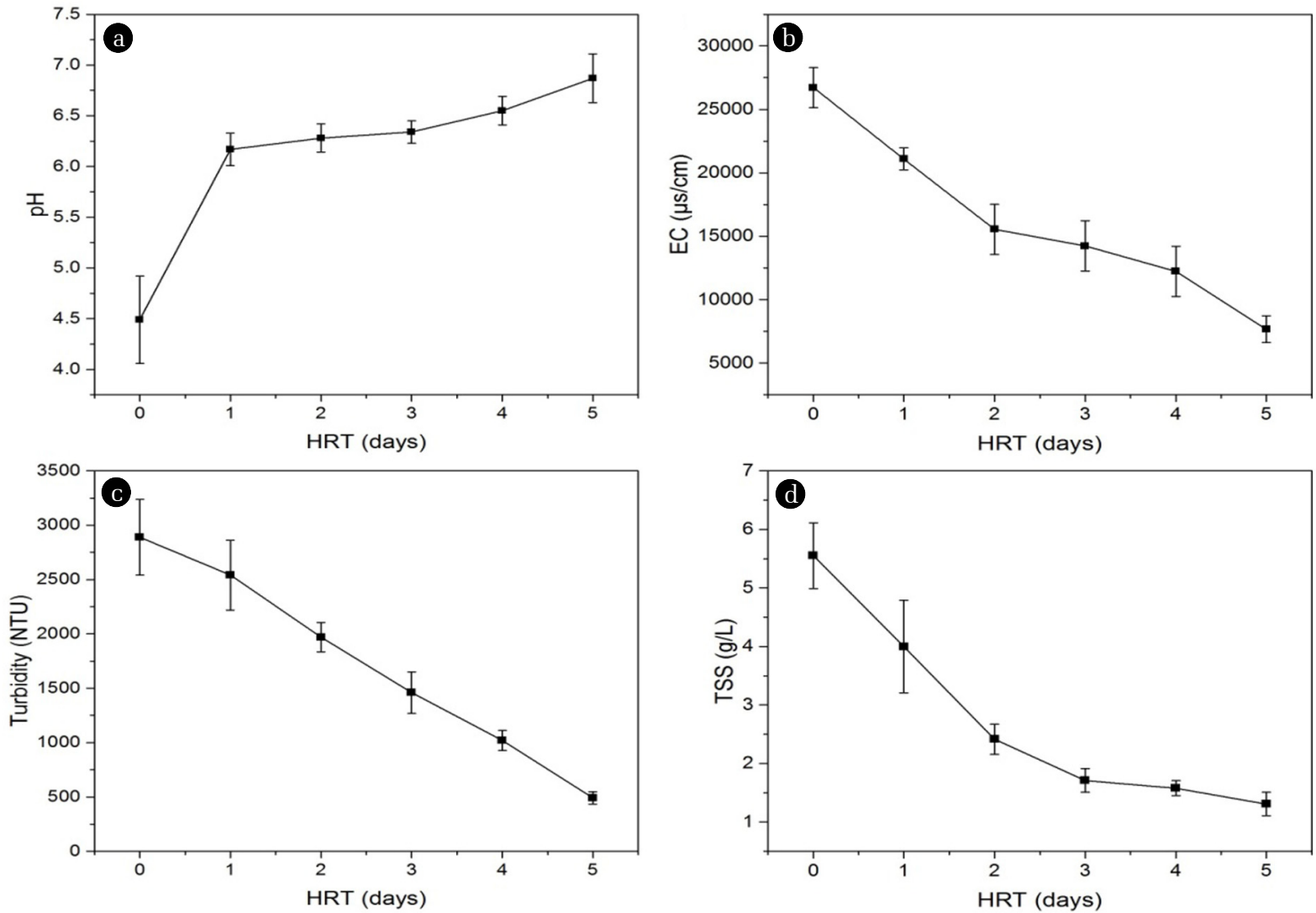

Fig. 3. Evolution of (a) $\mathrm{pH}$, (b) EC, (c) Turbidity and (d) TSS in function of HRT during UASB treatment.

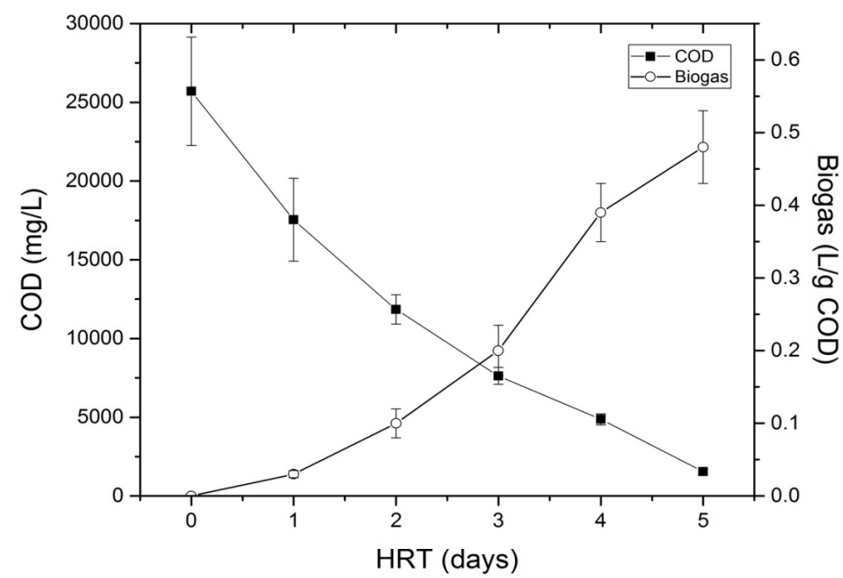

Fig. 4. Evolution of COD and biogas production in function of HRT during UASB treatment.

during the ascending leachate path-way in the reactor, and is accompanied by biogas production. Furthermore, these results and those obtained by other studies in the literature [33, 34] have lead towards the same conclusions. They also approved that there was a strong correlation between different physicochemical parameters. These are justified by various parameters reduction in short and optimal time to achieve very acceptable values corresponding to the treatment of such an effluent.
Table 4. Schedule for Characterization of Leachate before and after Treatment with UASB

\begin{tabular}{ccc}
\hline No. of Sample & HRT (days) & Temperature $\left({ }^{\circ} \mathbf{C}\right)$ \\
\hline Raw leachate & 0 & $22 \pm 2.65$ \\
Average E1 & 1 & $25 \pm 2.65$ \\
Average E2 & 2 & $25 \pm 1.73$ \\
Average E3 & 3 & $26 \pm 2.65$ \\
Average E4 & 4 & $26 \pm 2.00$ \\
Average E5 & 5 & $26 \pm 2.65$ \\
\hline
\end{tabular}

\section{Conclusions}

In this preliminary study, physicochemical characteristics of fresh leachate before landfilling in Kasba Tadla city were determined and interpreted. Moreover, assessment and feasibility study of UASB technique was carried out by its capacity and efficiency to treat leachate and reduce pollutant load in a short time. However, different conclusions were drown:

- A huge amount of fresh leachate was produced during collection of household wastes in Kasba Tadla city due to the high organic matter and moisture contents.

- Treatment using UASB technique was feasible and effective as the COD was reduced to $94 \%$ after an HRT of 5 days, 
with an average temperature of $25^{\circ} \mathrm{C}$, and a convergence of these effluents towards neutrality. The process was effective even in the early hours of the system startup.

- Climatic conditions of the study area were very favorable for the technique operation. Therefore, it is possible to reach performance more than 95\% COD reduction during summer.

- The choice of UASB reactor model was satisfactory for treating an amount of $1 / 10$ of the daily produced amount. This model results would be useful to design an UASB reactor which have a permanent processing flow and can treat effluent with high organic load [4, 35].

At this stage, the current study did not go beyond these observations, but it opens interesting perspectives such as: Determination of UASB reactor dimensions and optimum temperature in order to reach a reduction yield higher than 95\%; Combination of UASB technique and forced evaporation technique, investigation currently in progress, to determine possible use of produced gases for heating during the cold season and have a material evaporation performance.

\section{References}

1. Moroccan K. Royaume du Maroc Secrétariat d'Etat auprès du Ministère de l'Energie, des Mines, de l'Eau et de l'Environnement chargé de l'Eau et de l'Environnement, Programme de gestion et de protection de l'environnement (PGPE), composante Région Nord. Guide de surveillance des décharges contrôlées; 2012. p.60.

2. Souabi S, Touzare K, Digua K, Chtioui H, Khalil F, Tahiri M. Triage et valorisation des déchets solides à la décharge publique de la ville de Mohammedia. Les Technologies de laboratoire 2011;6:121-130.

3. Kaschl A, Römheld V, Chen Y. The influence of soluble organic matter from municipal solid waste compost on trace metal leaching in calcareous soils. Sci. Total Environ. 2002;291:45-57.

4. Trebouet D, Berland A, Schlumpf J.P, Jaouen P, Quemeneur F. Traitement de lixiviats stabilisés de décharge par des membranes de nanofiltration. Revue des sciences de l'eau/Journal of Water Science 1998;11:365-382.

5. Foresti, E. Perspectives on anaerobic treatment in developing countries. Water Sci. Technol. 2001;44:141-148.

6. Zeeman G, Lettinga G. The role of anaerobic digestion of domestic sewage in closing the water and nutrient cycle at community level. Water Sci. Technol. 1999;39:187-194.

7. Liu J, Zuo JE, Yang Y, Zhu SQ, Kuang SL, Wang KJ. An autotrophic nitrogen removal process: Short-cut nitrification combined with ANAMMOX for treating diluted effluent from an UASB reactor fed by landfill leachatee. J. Environ. Sci-China. 2010;22:777-783.

8. Sun HW, Yang Q, Peng YZ, Shi XN, Wang SY, Zhang SJ. Advanced landfill leachate treatment using a two-stage UASB-SBR system at low temperature. J. Environ. Sci-China. 2010;22:481-485.

9. Lettinga G, Van Velsen A, Hobma SW, De Zeeuw W, Klapwijk A. Use of the upflow sludge blanket (USB) reactor concept for biological wastewater treatment, especially for anaerobic treatment. Biotechnol. Bioeng. 1980;22:699-734.

10. Wiegant WM. Experiences and potential of anaerobic wastewater treatment in tropical regions. Water Sci. Technol. 2001;44:107-113.

11. Seghezzo L. Anaerobic treatment of domestic wastewater in subtropical regions: publisher not identified; 2004.

12. Moroccan K, Ministère L. Cahier des charges pour la gestion déléguée des services de propreté comprenant la collecte et l'évacuation des déchets ménagers et assimilés et le nettoiement des voies et place publiques, ainsi que l'évacuation des produits de nettoiement de la ville de Kasba Tadla. Morocco; 2008. p. 49.

13. Zahrani F. Contribution à l'élaboration et validation d'un protocole d'audit destiné à comprendre les dysfonctionnements des centres de stockage des déchets (CSD) dans les pays en développement. Application à deux CSD: Nkolfoulou (Cameroun) et Essaouira (Maroc) (Doctoral dissertation, INSA de Lyon); 2006.

14. Rodier J. L'analyse de l'eau. 7eme édition. Paris: Dunot; 1984.

15. Rassam A, Bourkhiss B, Chaouch A, El Watik L, Chaouki H, Ghannami M. Caractérisation de lixiviats des décharges contrôlées au Maroc et solutions de traitement : cas de lixiviats de la ville d'Al Hoceima. Environnement ScienceLib, 2011.

16. Moroccan Kingdom, Haut-Commissariat au Plan. Statistiques environnementales au Maroc. Rabat: le Plan Bleu; 2006. p.108.

17. Tabet-Aoul M. Types de traitement des déchets solides urbains évaluation des couts et impacts sur l'environnement. Rev. Energ. Ren.: Production et Valorisation-Biomasse, 2001. p. 97-102.

18. Hwang IH, Aoyama H, Matsuto T, Nakagishi T, Matsuo T. Recovery of solid fuel from municipal solid waste by hydrothermal treatment using subcritical water. Waste Manage. 2012;32:410-416.

19. Beylot A, Villeneuve J. Environmental impacts of residual Municipal Solid Waste incineration: A comparison of 110 French incinerators using a life cycle approach. Waste Manage. 2013;33:2781-2788.

20. Santibañez-Aguilar JE, Ponce-Ortega JM, González-Campos JB, Serna-González M, El-Halwagi MM. Optimal planning for the sustainable utilization of municipal solid waste. Waste manage. 2015;33:2607-2622.

21. Ajir A. Gestion des déchets solides au Maroc: Problématique et approche de développement. In: Proceedings of International Symposium on Environmental Pollution Control and Waste Management; 2002; Tunis. p. 740-747.

22. Ye JX, Mu YJ, Cheng X, Sun DZ. Treatment of fresh leachate with high-strength organics and calcium from municipal solid waste incineration plant using UASB reactor. Bioresource Technology. 2011;102:5498-5503.

23. Renou S, Poulain S, Gagnaire J, Marrot B, Moulin P. Lixiviat de centre de stockage: déchet généré par des déchets. L'Eau L'industrie Les Nuisances 2008;310:37.

24. Schlumpf JP, Trebouet D, Quemeneur F, Maleriat JP, Jaouen P. Réduction de la DCO dure des lisiers de porc et lixiviats par nanofiltration. Revue des sciences de l'eau/Journal of Water 
Science 2001;14:147-155.

25. Robinson $\mathrm{HD}$, Gronow JR. A review of landfill leachate composition in the UK. In: Proceedings Sardinia, Fourth International Landfill Symposium; 1993 Jan; Cagliary. p.821-832.

26. Shin HS, Han SK, Song YC, Lee CY. Performance of UASB reactor treating leachate from acidogenic fermenter in the two-phase anaerobic digestion of food waste. Water. Res. 2001;35:3441-3447.

27. Peng YZ, Zhang SJ, Zeng W, Zheng SW, Mino T, Satoh $\mathrm{H}$. Organic removal by denitritation and methanogenesis and nitrogen removal by nitritation from landfill leachate. Water. Res. 2008;42:883-892.

28. Jokela JPY, Kettunen RH, Sormunen KM, Rintala JA. Biological nitrogen removal from municipal landfill leachate: low-cost nitrification in biofilters and laboratory scale in-situ denitrification. Water. Res. 2002;36:4079-4087.

29. Michaud JP. Chapter 3 - Streams: Total Suspended Solids and Turbidity in Streams. In: A Citizen's Guide to Understanding and Monitoring Lakes and Streams. Puget
Sound Water Quality Authority; 1991.

30. Wetzel RG. Limnology: lake and river ecosystems. 3rd ed. San Diego: Gulf Professional Publishing; 2001.

31. Chen ZQ, Hu CM, Muller-Karger F. Monitoring turbidity in Tampa Bay using MODIS/Aqua 250-m imagery. Remote Sens Environ. 2007;109:207-220.

32. Reinhart DR, AlYousfi AB. The impact of leachate recirculation on municipal solid waste landfill operating characteristics. Waste Manage. Res. 1996;14:337-346.

33. Bohdziewicz J, Kwarciak A. The application of hybrid system UASB reactor-RO in landfill leachate treatment. Desalination. 2008;222:128-134.

34. Neena C, Ambily PS, Jisha MS. Anaerobic degradation of coconut husk leachate using UASB-reactor. J. Environ. Biol. 2007;28:611-615.

35. Khattabi H, Aleya L, Mania J. Lagunage naturel de lixiviat de décharge. Revue des sciences de l'eau/Journal of Water Science 2002;15:411-419. 